\title{
A ANÁLISE DO DISCURSO E QUESTÕES SOBRE A LINGUAGEM
}

\author{
Ângela Maria Walesko Piovesan* \\ Carla Maria Forlin* \\ Denise Mohr* \\ Juliana Zeggio Martinez* \\ Sandra Lopes Monteiro** \\ Zelir Franco*
}

\section{RESUMO}

Com subsídios oferecidos pela obra Análise de discurso: princípios e procedimentos de Eni Orlandi (2003), este texto aborda questões sobre a linguagem e apresenta reflexões sobre a Análise do Discurso e sua influência na formação de professores de línguas.

Palavras-chave: Análise do discurso; formação de professores; interculturalidade; sujeito; função-autor

\section{APRESENTAÇÃO}

Este artigo tem como objetivo verificar em que medida a obra Análise de discurso: princípios e procedimentos de Eni Orlandi (2003) contribui para o estudo da Análise do Discurso e qual a influência dessa obra na formação de professores de línguas.

Para apresentar o que ela chamou de "Pequenas aulas" sobre pontos da Análise do Discurso (doravante $\mathrm{AD}$ ), ou como ela própria afirma, no campo de questões sobre a linguagem, Orlandi explora diferentes aspectos dessa área de conhecimento.

Embora não sistematizados, desde a Antiguidade, empreendem-se estudos sobre a linguagem e sua produção de sentidos. No século XIX, as noções de sujeito e de linguagem, categorias nas quais se apoiavam as Ciências Humanas e Sociais, sofrem mudanças significativas graças a contribuições dos estudos da lingüística e da psicanálise. Essas novas noções, posteriormente, segundo Orlandi, instigarão estudos de análise do discurso nos quais se reflete sobre a linguagem, sujeito, história e ideologia. No entanto, somente nos anos sessenta é que a $\mathrm{AD}$ ganha força com a lingüística, o marxismo e a psicanálise, mas não se atém a esses campos do conhecimento, indo bem além de suas fronteiras.

\footnotetext{
* Alunas do Curso de Pós-Graduação em Letras (área de concentração: estudos lingüísticos) da Universidade Federal do Paraná.

** Sandra Lopes Monteiro é doutora em Semiótica e Lingüística Geral. Atualmente é professora do Curso de Letras Francês e professora do Curso de Pós-graduação em Letras da Universidade Federal do Paraná (área de conhecimento: Estudos Lingüísticos).
} 
Segundo a autora, sempre houve diferentes maneiras de se abordar a linguagem. Entre elas, por exemplo, a que concebe a língua como um sistema de signos, ou então, a que entende a linguagem como um sistema de regras formais. A AD, por sua vez, entende a linguagem como mediação necessária entre o homem e a realidade social. Esta mediação é feita pelo discurso, ou seja, pelas práticas discursivas nas quais o homem se insere, sendo capaz de significar e significar-se. O discurso torna possível tanto a permanência e a continuidade, quanto o deslocamento e a transformação do homem e da realidade na qual vive.

A representação da realidade das pessoas, ou seja, do seu cotidiano, é permeada por símbolos. E diante deles, o processo de interpretação se desdobra. A AD permite uma relação mais próxima com a linguagem, uma vez que o discurso é a prática da linguagem e concebe-a como a intermediação entre o homem e a realidade social. Desde a antiguidade vários estudos foram realizados, embora não sistematizados, sobre a linguagem e sua produção de sentidos, o que é de interesse direto da AD. No entanto, somente nos anos de 1960 é que a AD ganha força com a lingüística, o marxismo e a psicanálise, mas não fica preso nestes campos do conhecimento, indo bem além de suas fronteiras (ORLANDI, 2003)

Ao constituir o discurso como seu objeto, a $\mathrm{AD}$ relaciona a linguagem à sua exterioridade: não trabalha com a língua enquanto sistema abstrato, mas com a língua no mundo, com homens expressando-se oralmente e por escrito, falando produzindo sentidos, enquanto sujeitos e enquanto membros da sociedade. Em conseqüência, considera o lingüístico como parte da prática do discurso $^{1}$ e vê a história e a sociedade como indissociáveis do fato que significam. Trata o discurso como palavra em movimento, prática de linguagem. A língua deve fazer sentido enquanto trabalho simbólico, que significa a partir do trabalho social, constitutivo do homem e da sua história. A linguagem deve ser entendida como mediação necessária entre o homem e a realidade natural e social.

Diferentemente da maneira como a comunicação entende a linguagem, ou seja, simples transmissão de mensagem de um emissor para um receptor, para a AD no discurso não há linearidade na disposição dos elementos do quadro comunicativo, pois a língua não é apenas código. As práticas discursivas são processos de identificação de sujeitos, de argumentação, de subjetivação e de construção da realidade, pois essas relações de linguagem são na verdade relações de sujeitos e de sentidos e seus efeitos são múltiplos e variados.

\footnotetext{
${ }^{1}$ Entende-se discurso como efeito de sentido, pois é no discurso que se configura a relação entre língua, cultura e ideologia.
} 
Orlandi explica que constantemente temos a ilusão de que nossas palavras são originais, quando na verdade esquecemos involuntariamente que estamos sempre esquecendo o que já foi dito. Por isso, quando repetimos as palavras, ou seja, retomamos palavras já existentes, elas adquirem novamente sentido e nos dão a ilusão de originalidade. O que não podemos esquecer, de fato, é a condição primeira da linguagem: a de ser sempre uma incompletude. Nem os sujeitos, nem os discursos e nem os sentidos estão prontos e acabados. Eles estão sempre se fazendo num movimento constante do simbólico e da história.

Estes sentidos inacabados resultam das relações de força (poder) nas quais estamos inseridos. A construção de sentido se dá a partir do lugar no qual a fala do sujeito é constituída. Como nossa sociedade é constituída por relações hierarquizadas, essas relações de força são sustentadas pelo poder desses diferentes lugares, que se fazem valer na comunicação.

Para trabalhar o sentido, a AD reúne três áreas de conhecimento em suas articulações contraditórias: a) a teoria da sintaxe e da enunciação; b) a teoria da ideologia, e c) a teoria do discurso.

Para abordar o processo de produção de sentidos e sua relação com a ideologia, Orlandi introduz uma noção que considera básica na $\mathrm{AD}$ - a de formação discursiva ${ }^{2}$. Se as palavras não têm um sentido em si mesmas, é porque derivam seus sentidos das formações discursivas em que se inscrevem. As formações discursivas, por sua vez, representam no discurso as formações ideológicas ${ }^{3}$. Desse modo, os sentidos sempre são determinados ideologicamente.

A questão do sentido é fundamental para a $\mathrm{AD}$, pois a linguagem é linguagem porque faz sentido, e a linguagem só faz sentido porque se inscreve na história: “O dizer não é propriedade particular. As palavras não são só nossas. Elas significam pela história e pela língua. (...) O sujeito diz, pensa que sabe o que diz, mas não tem acesso ou controle sobre o modo pelo qual os sentidos se constituem nele.” (ORLANDI, 2003, p. 32). Assim, a AD rompe com a concepção de sentido como projeto de autor, rompe com a idéia de um sentido originário a ser descoberto.

\footnotetext{
${ }^{2}$ Formações discursivas: conjunto de enunciados histórica e socialmente inscritos, relacionando-se com uma identidade enunciativa associada a uma comunidade social, definindo-lhe objetos do discurso, conceitos, escolhas temáticas e, por vezes, gênero preferencial. Pode-se, então, falar de uma FD comunista, católica, feminista ou ainda científica, médica ou acadêmica.

${ }^{3}$ Formações ideológicas: modo de agir e de pensar de determinado grupo dentro da sociedade, constituindo "um conjunto complexo de atitudes e de representações que não são nem individuais nem universais”. (Haroche et al., 1971 apud Brandão, 1995, p. 38).
} 
A autora explica que mesmo sem a intenção consciente, o que falamos é afetado pela língua e pela história, pois os sentidos não estão somente nas palavras, mas na relação com a exterioridade, nas condições em que eles são produzidos e que não dependem unicamente das intenções dos sujeitos. Para a AD, a linguagem está materializada na ideologia e a ideologia se manifesta na língua, pois não há discurso sem sujeito, sujeito sem ideologia, nem sujeitos e sentidos estão completos. O discurso é o lugar possível no qual se observa esta relação entre língua e ideologia. Ao mesmo tempo, a AD tenta entender como os objetos simbólicos produzem sentidos, isto é, como eles estão investidos de significância para e por sujeitos. Segundo Orlandi, explorar de maneira diferente a relação de sentido construída através do simbólico tem sido a grande contribuição da AD.

A ideologia não é vista como conjunto de representações, como visão de mundo ou ocultação da realidade, mas como efeito da relação necessária do sujeito com a língua e com a história. Por outro lado, é também a ideologia que faz com que haja sujeitos. Para Pêcheux (ORLANDI, 2003, p. 49), o mundo não é diretamente apreensível quando se trata de significação, pois o vivido dos sujeitos é constituído pela ideologia.

Nosso imaginário, segundo Orlandi, não surge do nada, mas sim do modo como as relações sociais se inscrevem e são regidas na história por relações de poder. A AD então encontra sua função ao atravessar esse imaginário que condiciona os sujeitos em suas discursividades, para então tentar explicar o modo como os sentidos estão sendo produzidos e para, enfim, ajudar os falantes a compreender melhor o que está sendo dito.

A autora também distingue inteligibilidade, interpretação e compreensão. A inteligibilidade dá sentido à língua. A interpretação é o sentido, pensando-se o co-texto e o contexto imediato. Compreender é saber como um objeto simbólico (enunciado, pintura etc.) produz sentido. A compreensão procura explicitar os processos de significação presentes no texto, compreendendo como os sentidos se constituem. Enfim, não há sentido sem interpretação, e não há interpretação sem a presença da ideologia que é a condição básica para a constituição dos sujeitos e dos sentidos.

No que diz respeito à interpretação, uma parte é de responsabilidade do analista e a outra deriva, segundo os preceitos da $\mathrm{AD}$, da sua sustentação no rigor do método e no alcance teórico da $\mathrm{AD}$. Ao tratar da interpretação como dispositivo de análise, a autora considera que existem dois momentos dessa análise. No primeiro, a interpretação faz parte do objeto da análise e, no segundo, é preciso compreender que não há descrição sem interpretação - o próprio analista está envolvido na interpretação. A partir de diversos conceitos que podem ser mobilizados pelo analista, é possível fazer distintos recortes conceituais. 
Uma análise não é igual à outra. Um mesmo analista, formulando uma questão diferente, também poderá mobilizar conceitos diversos. Feita a análise, o analista interpretará os resultados de acordo com os instrumentos teóricos dos campos disciplinares de que partiu. Disso depende também o alcance de suas conclusões.

Finalmente, o que acreditamos ser a grande contribuição da $\mathrm{AD}$ para a lingüística é que ela nos permite uma relação menos ingênua com a linguagem (ORLANDI, 2003, p. 9), visto poder a) problematizar as maneiras de ler, por levar o sujeito falante ou o leitor a se indagar sobre o que produz e o que ouve; b) levar o indivíduo a perceber que não pode não estar sujeito à linguagem, a seus equívocos, a sua opacidade; c) mostrar que não há neutralidade, e d) saber que a entrada no simbólico é irremediável e permanente: estamos comprometidos com os sentidos e o político.

\section{A ANÁLISE DO DISCURSO E AS MUDANÇAS SIGNIFICATIVAS NA FORMAÇÃO DE PROFESSORES DE LINGUAGEM}

Muito se tem discutido sobre a linguagem nas últimas décadas. Cada vez mais encontramos estudos e pesquisas que têm proporcionado novas e diferentes reflexões sobre o que vem a ser linguagem.

Desde Sausurre, a linguagem sempre foi vista como um processo perfeito de comunicação, de trocas de informações entre emissor e receptor, enfim, a linguagem entendida como sinônimo de código. No entanto, pesquisadores como Orlandi (2003), Freitas (2004) e Jordão (2005) afirmam que, no século XXI, não podemos mais ser tão ingênuos a ponto de pensarmos que a linguagem se constitui em uma simplicidade e transparência de trocas de informações: a linguagem além de código, é discurso ${ }^{4}$.

A AD tem sido uma das linhas teóricas de muitas das pesquisas que, por sua vez, têm trazido grandes benefícios para os profissionais que trabalham com a linguagem, como, por exemplo, os professores de línguas nas escolas regulares. Esses passam a entender a linguagem não somente como código, mas como discurso.

\footnotetext{
${ }^{4} \mathrm{O}$ discurso é uma dupla dispersão: por um lado o cruzamento de vários dizeres; e por outro, as várias posições que o sujeito pode ocupar. Sendo então o discurso heterogêneo: "quanto à natureza dos diferentes materiais simbólicos; (...) quanto à natureza das linguagens; (...) quanto às posições do sujeito” (ORLANDI, 1999, p. 70). O discurso não é de forma nenhuma homogêneo, mas é marcado pela multiplicidade e alteridade, pois as palavras são sempre repletas de sentidos, e as palavras vêm sempre de um já-dito na fala do outro: "nenhuma palavra é 'neutra', mas inevitavelmente 'carregada', 'ocupada', 'habitada', atravessada' pelos discursos nos quais 'viveu sua existência socialmente sustentada' (AUTHIER-REVUS, 1990, p. 27)”.
} 
Ao mesmo tempo em que esses estudos (BECHEL, 2006; DELONG, 2005; DUNIN, 2005) levam a refletir sobre as implicações que as perspectivas de mundo de cada indivíduo acarretam sobre o ‘conteúdo' e a maneira de ensinar, eles proporcionam uma grande discussão sobre a função da linguagem na escola, conduzindo os professores de línguas a entender melhor os pressupostos que norteiam a sua formação.

Segundo Jordão (2006), os professores de língua em sala de aula possuem normalmente embasamentos teóricos que não sabem muito bem explicar de onde vieram ou como se enraizaram tão fortemente no seu fazer pedagógico; são esses embasamentos que moldam a concepção de mundo e informam as atitudes e escolhas do indivíduo. Segundo a autora, é necessário estar sempre atento a esses pressupostos que de certa forma orientam ações, pois certamente quando entramos em uma sala de aula, assim como nossos alunos, levamos conosco uma série de concepções do que significa ensinar e aprender línguas (cf. JORDÃO, 2006).

Os estudos da $\mathrm{AD}$ têm contribuído para ampliar os horizontes dos professores de línguas estrangeiras e língua materna, pois permitem esse novo olhar para a incompletude do sujeito, para a ausência de neutralidade da linguagem e dos sentidos. Hoje, os professores estão mais conscientes da ilusão de se pensar na linguagem como algo transparente, como se houvesse um sentido único e verdadeiro nos textos. Nossa função, enquanto professores de linguagem, passou a ser a de propor discussões e novas reações sobre os jogos simbólicos permeados por ela, ao invés de sermos somente reveladores de "uma verdade oculta” presente nos textos.

Entendendo o processo de interpretação como incompleto e obscuro, compreendemos, por exemplo, que o processo de leitura na escola é atividade fundamental para que nossos alunos tenham contato com outras interpretações de mundo, e assim possam construir suas identidades. Tanto a educação geral quanto o ensino de línguas estrangeiras são ótimas oportunidades para que alunos tenham contato com o outro, com o que é diferente do seu modo particular de ser e possam então entender melhor quem são e quem são os outros com quem interagem, ou melhor, com quem se engajam discursivamente (cf. FREITAS, 2004).

Infelizmente, boa parte do trabalho com a linguagem desenvolvida nas escolas ainda reflete uma visão da língua somente como código. Mesmo as atividades de leitura ainda são vistas como uma representação de uma verdade que está transparente no texto. A principal conseqüência dessa concepção de ensino da linguagem é não permitir com que alunos se percebam, nem construam suas realidades, uma vez que não estão construindo interpretações. 
Como professores, é importante lembrar que atualmente nossos alunos estão sendo formados para assumirem uma posição no mundo (cf. JORDÃO, 2005), e não mais somente para arranjarem um bom emprego (até porque formação não é mais garantia de bom trabalho, se é que algum dia foi). É preciso refletir sobre a maneira como a sociedade da qual fazemos parte funciona, uma vez que estamos (nós e todos os nossos alunos) inseridos em relações hierárquicas de poder. E, sem podermos fugir dessas relações, o melhor seria que nós todos aprendêssemos a perceber estas construções de sentidos para melhor nos beneficiarmos delas (cf. FREITAS, 2004).

No entanto, este trabalho deve ser feito com cuidado, pois não podemos também ter a ilusão de que nossa posição enquanto professor é neutra ou que nossa concepção de mundo é a verdadeira. Precisamos ter cautela quando ocupamos a posição professor, pois esta carrega autoridade, e esta legitimidade conquistada pela posição hierárquica pode apagar outras vozes presentes na sala de aula. Não deveríamos esquecer que nossa voz de professor é uma em meio a tantas outras presentes na aula, que ela também não é neutra nem é a reprodução da realidade ou verdade. Nossa visão é igualmente permeada pelo simbólico, pois também estamos usando lentes permeadas pela nossa história e pelos objetos simbólicos que constroem nosso mundo.

Enfim, não deveríamos esquecer que estamos inseridos em construções de realidade a todo o momento, para assim percebemos que

ensinar uma língua estrangeira é possibilitar condições para que, ao se constituir cidadão, o aprendiz tenha ampliado o acesso a outros modos de perceber e fazer sentido do mundo, bem como a outras formas de funcionamento ou posicionamento (práticas sociais) desse mundo. (cf. FREITAS, 2004)

Temos uma enorme responsabilidade social enquanto professores de linguagem, pois

conhecer uma língua estrangeira é essencial não apenas para que se possa receber e transmitir mensagens, mas também e principalmente porque uma língua, materna ou estrangeira, não é só um código através do qual se transmitem informações: uma língua é um espaço de construção de conhecimento, um espaço no qual se delimitam possibilidades de entendimento e se moldam identidades; uma língua é um espaço múltiplo de potencialidades e de procedimentos interpretativos hierarquizados, ou seja, uma arena de conflitos, como a ela se referiu Bakhtin. (cf. JORDÃO, 2005) 


\section{A AD E O ESTUDO DOS ASPECTOS INTERCULTURAIS NO ENSINO DE LÍNGUAS}

Aqui apresentaremos a relação entre a AD e a abordagem comunicativa intercultural na aquisição de uma língua estrangeira. Neste estudo, entende-se por abordagem comunicativa intercultural (SANTOS, 2004) aprender uma língua aprendendo sua cultura, ou melhor, vivenciando a língua como cultura. Vivenciar a língua como cultura significa mais do que uma simples eleição de enfoques metodológicos, é, antes de tudo, pensar o processo de ensino/aprendizagem de língua estrangeira como algo mais amplo, que não se resume à simples apreensão de aspectos estruturais de uma língua nova, 'estranha', mas o contato com outro sistema de valores, de 'leitura do mundo', dentro do qual se inclui a língua. A cultura, então, que normalmente assume o papel secundário nesse processo, em detrimento da forma lingüística, passa a ser a porta de entrada, o elemento fundador a partir do qual a experiência de ensinar e aprender se edifica em busca da construção de um diálogo intercultural. Professores e alunos como sujeitos culturais que são, interagindo em busca do objetivo de ensinar e aprender uma nova língua-cultura, colocam-se em situação de confronto, de troca e de negociação de mundos culturais e simbólicos diversificados.

Para entender a relação entre o ensino de língua estrangeira e a interculturalidade, pesquisou-se o ensino de inglês para alunos do quarto ciclo (7. a $8 .^{a}$ séries) do Ensino Fundamental de uma escola privada e de uma escola pública da cidade de Curitiba, buscando compreender os interesses e motivações desses alunos com relação à cultura estrangeira. Objetivava-se também verificar os diversos estereótipos culturais presentes em seu discurso. Percebemos durante um estudo piloto e também durante anos de convivência com outros professores da área, que, por falta de tempo ou de conhecimento, muitos professores não aprofundam a leitura de textos apresentados nos livros didáticos. Além disso, enquanto habilidades lingüísticas são desenvolvidas, aspectos interculturais ${ }^{5}$ da língua não são considerados.

A $\mathrm{AD}$ considera que a ideologia se materializa na linguagem, faz parte do seu funcionamento e se liga à interpretação enquanto fato fundamental que atesta a relação da história com a língua. A conjunção língua/história só pode se dar pelo funcionamento da

\footnotetext{
${ }^{5}$ Interculturalidade: comunicação entre povos de diferentes culturas étnicas e sociais dentro dos limites de uma nação ou encontro de pessoas de diferentes culturas e línguas além das barreiras políticas de estados ou países; a interculturalidade também é vista como o desenvolvimento de uma habilidade “diplomática” de perceber as diferenças culturais da perspectiva da compreensão bem informada. Ou seja, o indivíduo se posiciona porque conhece aquilo de que está falando (KRAMSCH, 2000).
} 
ideologia. No que se refere à relação abordagem comunicativa e interculturalidade, é necessário que se considere a visão social da língua (e esta é indissociável da cultura e, portanto, da ideologia), partindo-se da observação de que leitores e escritores estão social, política, histórica e culturalmente posicionados ao agirem para a construção do significado; uma visão de língua como fenômeno fundamental da comunicação entre pessoas ou grupos sócio/culturalmente diferentes, que pressupõe um ensino/aprendizagem sensíveis à pessoa humana, ao seu momento histórico de vivência e às relações que estabelece com o mundo e com as pessoas à sua volta.

Quanto à questão sócio-histórica e ideológica da linguagem, é importante lembrar que o professor de língua estrangeira é muito mais do que um mero transmissor de um sistema lingüístico; é acima de tudo um grande agente na formação ideológica de seus alunos e para que se evite que estereótipos culturais ou crises de identidade se instalem, é crucial que o professor saiba trabalhar com o seu discurso oral/escrito, com o de seus alunos ou de outros.

No estudo realizado com os alunos do ensino fundamental ficou demonstrado que é imprescindível pressupor que as funções sociais da língua e de sua historicidade sejam recuperadas, o que pode ser efetivado por meio do emprego de uma abordagem que pressuponha o ensino comunicativo e intercultural de leitura em língua estrangeira.

No que se refere ao tratamento do texto, Orlandi discute textualidade e discursividade, apresentando a definição de texto enquanto uma unidade lingüístico-histórica que significa. Trata o texto como discurso e observa que não é a extensão que delimita um texto e nem o fato de ser oral ou escrito. Na aplicação do estudo piloto, observaram-se quais tipos de textos são utilizados em sala de aula (gênero, formação ideológica e discursiva presentes no texto) e como os textos provenientes dos livros didáticos são trabalhados com relação ao aspecto intercultural.

A partir da pilotagem dos instrumentos de coleta de dados realizada em 2005, observou-se que os professores restringem o trabalho com textos à mera tradução e/ou os utilizam como pretexto para a introdução de conteúdos gramaticais. Não há nenhum tipo de análise do discurso (texto) feita pelos professores. Textos sobre aspectos culturais tornam-se, na visão dos alunos, “modelos de cultura”, que geralmente são considerados pelos estudantes melhores do que os da brasileira. Um diálogo simples pode apresentar, mesmo que em

\footnotetext{
${ }^{6}$ PIOVESAN, Ângela Maria Walesko. Abordagem comunicativa intercultural no ensino de língua estrangeira: um estudo em sala de aula com a habilidade de leitura em inglês (Dissertação de mestrado). Curitiba: UFPR, 2006.
} 
“entrelinhas”, informações que possibilitem discussões sobre interculturalidade em sala de aula.

No estudo realizado, considerou-se o texto enquanto discurso e procedeu-se à análise do material escrito utilizado pelos professores nas aulas de leitura e dos diferentes discursos empregados pelos informantes da pesquisa (professores e alunos), sujeitos do discurso. Utilizou-se, para isto, o conceito de sujeito do discurso de Mussalim (2003, p. 110):

(...) aquele que ocupa um lugar social e a partir dele enuncia, sempre inserido no processo histórico que lhe permite determinadas inserções e não outras. (... ) o sujeito não é livre para dizer o que quer, mas é levado, sem que tenha consciência disso, a ocupar seu lugar em determinada formação social e enunciar o que lhe é possível a partir do lugar que ocupa.

No estudo, utilizou-se a visão da Análise do Discurso Americana que considera a intenção dos sujeitos numa interação verbal como um dos pilares que a sustenta; os sujeitos são condicionados por uma determinada ideologia que predetermina o que poderão ou não dizer em determinadas conjunturas histórico-sociais. (MUSSALIM, 2003, p. 113). Essa visão relaciona-se ao tema interculturalidade na medida em que os professores de língua estrangeira sejam considerados e se considerem educadores, colaboradores na formação dos futuros cidadãos do mundo e não apenas transmissores de um sistema meramente lingüístico, sem função social.

O discurso do professor certamente exerce influência na formação ideológica dos alunos e pode gerar, ou não, a criação de estereótipos culturais que influenciarão o aluno quanto à sua forma de pensar e agir socialmente. Se o professor não possui nenhum tipo de formação em relação ao trabalho intercultural, por exemplo, se limitará a repassar informações estanques sobre determinada cultura (geralmente a americana, mais enfatizada na rotina brasileira), podendo gerar nos alunos a noção de que tudo (produtos materiais, cultura de uma forma geral - arte, música etc.) é melhor do que o que temos em nosso país.

Se, por outro lado, o professor souber abordar e desenvolver conteúdos interculturais (entre outros conteúdos) em sala de aula, promovendo a comparação entre o Brasil e outras culturas, levará os alunos à compreensão de que não existem culturas melhores ou piores, apenas diferentes, ou seja, com seus significados e práticas sociais marcadas por suas respectivas ideologias. Poderá, então, amenizar a força do imperialismo sócio-cultural de outras culturas sobre nosso país, prestigiando a identidade cultural do aluno. 


\section{O COMPLEXO DOS SUJEITOS NO TEXTO LITERÁRIO DIDÁTICO}

Orlandi (2003, p. 73/76) aponta algumas características do discurso que, segundo a $\mathrm{AD}$, formam o autor. Ela observa que o funcionamento do discurso acontece entre o real e o imaginário. O real é representado pelo sujeito e evidencia a identidade caótica do discurso, que se traduz na fragmentação, na incompletude, na contradição. O imaginário é representado pelo papel do autor na materialização do texto e confere a ele a sensação de organização do discurso emprestando a ele características tais como a unidade, a coerência, a clareza e a não contradição. Desse modo, a autora afirma que o autor é o lugar em que se constrói a unidade do sujeito. Assim, na posição de autor, o sujeito adquire o sentimento (imaginário) de que seu discurso é finalmente estável e livre das armadilhas da confusão de sentidos.

A noção de que a autoria confere identidade ao sujeito está associada às forças de controle do sujeito no discurso. Orlandi observa que é Foucault (2001; 2004) quem melhor percebe as forças internas que detêm a tarefa de domesticar o discurso ou de controlar o caráter de acontecimento do discurso. Sendo assim, para Foucault, os discursos nada têm de espontâneo ou de particular, mas ao contrário, seus termos são sempre determinados pelas forças de poder que controlam a práxis humana. Assim, o caráter (imaginário) de fechamento, conferido ao discurso, recebe credibilidade graças às forças de poder que determinam seu “início" e seu "fim”. Para a AD, que faz distinção entre discurso e texto, o momento em que as forças de controle melhor alcançam o objetivo de inculcar a ilusão de acabamento do discurso é quando este se transforma em texto.

A realidade de que o sujeito não é autônomo na construção do discurso é elucidada no conceito de polifonia de Bakhtin (1981). Ao analisar o aspecto peculiar das personagens dos romances de Dostoiévski, em relação a outros romances em que as personagens não se constroem dialogicamente, Bakhtin evidencia como a enunciação pelas personagens de Dostoiévski é construída no exercício dialógico, entre as diferentes vozes que se confrontam e se avaliam em igualdade de espaço. Esta visão do discurso enquanto enunciação dialógica extrapola o campo da literatura em Bakhtin-Volochinov (1997), em que as concepções de dialogismo se estendem a todo tipo de discurso. Bakhtin e seu círculo mostram que em um enunciado concreto as vozes se avaliam, emitindo respostas ao discurso do outro. Neste exercício, as diferentes visões de mundo que constituem as vozes se confrontam em igualdade de espaço social. Sendo assim, no exercício dialógico um discurso nunca é produto de um único pensamento, de uma única voz. Ao ser pronunciado, o discurso se faz único para aquele momento sócio-interativo, mas é sempre mediado por juízos de valor de discursos já ditos; 
por outro lado, também não permanecerá intacto, mas antes sofrerá os efeitos de refração dos juízos de valor no confronto com as visões de mundo que constituem a voz do outro que com ele dialoga. Em Foucault, podemos perceber a interação/confronto dessas vozes mediadas pelas relações de poder que controlam a prática social.

As percepções de polifonia mediada pelas relações de poder permitem identificar os diferentes tipos de sujeito que comandam o texto de literatura que compõe livros didáticos de inglês como língua estrangeira. A identificação das diferentes vozes que autorizam o texto literário didático permite a percepção dos efeitos das forças de poder no aprendizado de inglês. Ao fazer parte do contexto didático, o texto de literatura é legitimado por um conjunto de sujeitos/autores que acaba por caracterizar o apagamento da identidade do autor “original” do texto. Desse modo, a autoria do texto de literatura no contexto de livros didáticos não se restringe ao nome do autor que supostamente escreveu o texto, mas antes se dilui entre um complexo de sujeitos discursivos. Estes diferentes sujeitos somam forças para legitimar determinado tipo de saber que é coerente com os interesses dos poderes dominantes.

A primeira voz a se apropriar do texto de literatura com fins didáticos é a editora de livros textos. Esta conta com os profissionais autores dos livros que são, geralmente, lingüistas. Na voz editorial, cujo objetivo é a obtenção do lucro pela comercialização da língua estrangeira, o texto de literatura perde seu caráter artístico e se transforma em instrumento que veicula informação fragmentada. Isso se deve ao fato de que, para os objetivos que regulam o mercado capitalista, não há interesse na formação reflexiva. O mercado de profissionais para a produção de bens de consumo, por exemplo, exige que seu trabalhador fale inglês a fim de acelerar a produtividade, mas não tolera que sua formação seja crítica a ponto de questionar os poderes que o controlam. Assim, a inclusão de uma narrativa de Ernest Hemingway ou de um poema de Doroty Parker, como parte dos elementos lingüísticos de um livro didático destinado ao aprendizado de inglês, pode se resumir na prática de aspectos gramaticais tais como a fixação de tempos verbais, conforme prática comum encontrada nos livros didáticos.

As outras vozes que compartilham do controle do texto literário são as das autoridades acadêmicas, nas figuras de coordenadores de cursos e de professores. Estes se transformam em co-autores do texto, responsáveis pela divulgação dos objetivos do texto literário didático em sala de aula. Estas vozes promovem interferências na autoria do texto literário à medida que divulgam os interesses propostos pelo manual didático e/ou promovem resistências, realizando adaptações e/ou cortes no texto de acordo com sua teoria da aula. 
O controle do texto literário por estes diversos sujeitos resulta na incoerência entre o discurso do manual do professor, que assegura um aprendizado da língua estrangeira sob os efeitos do exercício dialógico, e o que ocorre na prática real da língua estrangeira com esse tipo de texto que passou a assumir uma função didática. De acordo com o discurso didático, que se diz circular dentro da abordagem comunicativa, o texto literário deve promover o desenvolvimento dialógico na língua estrangeira, envolvendo o aluno enquanto sujeitoconstrutor do significado. No entanto, a característica de fragmentação de aspectos lingüísticos no exercício com o texto literário didático impõe ao aluno a condição de receptor passivo de mensagens cujos limites são pré-estabelecidos.

Além das forças de controle já mencionadas, o próprio texto literário, independentemente de onde circule, também não está livre das determinações do poder. O texto literário enquanto obra não é neutro; é antes controlado pela função-autor. A característica da função-autor é observada por Foucault (2001) em seu ensaio O Que é um autor? A função-autor é um conjunto de autorização do texto literário e revela como as forças de poder exercem o controle sobre este tipo de discurso. Foucault observa que o texto de literatura passou a ser controlado pelo mecanismo função-autor a partir do momento em que a crítica literária e a filosofia decretaram a morte do autor. O autor deveria sair de cena em prol da apreensão da "essência” da obra literária, que deveria bastar pelo significante da escrita e pela noção de obra.

Assim, a vida pessoal do autor e possibilidades de seu envolvimento enquanto sujeito na obra deveriam ser desconsiderados. No entanto, o desaparecimento do autor implicaria na perda do controle sobre o discurso de literatura. Assim, para garantir o controle, o poder não matou o autor, como disse, mas apenas o substituiu pela função-autor. A função-autor determina algumas condições para que o texto de literatura seja legitimado. Estas condições caracterizam o texto literário para que ele adentre na ordem do discurso. Uma das características de um texto que circula sob a função-autor é o seu caráter de propriedade.

Foucault (ibid., p. 274-275) observa que até a Idade Média a questão autoral não tinha nenhuma relevância. O que importava era o discurso em si, enquanto ato e não quem o pronunciou. No entanto, em dado momento da história, com o uso do discurso para atos de transgressão, o poder cria mecanismos para controlar o que é dito e por quem é dito. Estes mecanismos colocaram então o discurso no caráter de propriedade e surgiram com a criação de regras sobre os direitos do autor, bem como sobre as relações autores/editores e sobre os direitos de reprodução. A partir de então o discurso deixa de ser apenas um ato e passa a ser 
um produto, uma coisa, um bem. A idéia de obra enquanto propriedade é, portanto, uma das características da função-autor.

Outra característica de um texto que circula sob a função-autor é a exigência de sua identidade. Ainda que se pregue que o autor está morto, que sua identidade é separada do que ele escreve, o anonimato de uma obra não é suportado. Paradoxalmente, nossos valores culturais exigem que a obra tenha uma assinatura para ser legitimada. Outro aspecto que caracteriza a função-autor é o fato de o discurso receber a áurea de operação complexa: o discurso é legitimado pela autoridade do “poder criador”, a qual é reforçada pelo prestígio da escrita.

E, finalmente, a função-autor se caracteriza por remeter o autor à pluralidade de egos, pela força de elementos (signos), tais como pronomes, advérbios de tempo e de lugar, e a conjugação de verbos, que configuram o autor a um alter ego, que afirma o autor entre sua condição de escritor real e locutor fictício.

A mediação do texto de literatura pelas diferentes vozes do contexto didático e as diferentes vozes que caracterizam a função-autor evidenciam como o prestígio da literatura é autorizado no contexto do livro didático enquanto fonte digna de credibilidade para o aprendizado de inglês. O controle do discurso do texto literário didático é, portanto, exercido através deste grupo de sujeitos/“autores” que atuam no fortalecimento dos valores da cultura dominante. Caracterizando-se pela atuação na opacidade, sem assumir uma identidade individualizada e clara, estes sujeitos do discurso literário didático são os mediadores das relações de poder.

\section{ALGUMAS IMPLICAÇÕES DO CONCEITO DE FUNÇÃO-AUTOR}

Foucault evidencia que o mecanismo função-autor está impregnado de intenções de controle. Certos discursos, especialmente o discurso literário, devem ser legitimados pela função-autor por ser este o mecanismo de controle que lhes cabe na esfera de dominação em que o poder precisa controlar sem revelar as suas intenções. No entanto, o que incomoda Orlandi é a afirmação de Foucault de que certos tipos de texto não precisam de autoria. Segundo ele, discursos que envolvem a prática cotidiana formal tais como contratos, receitas técnicas, decretos, podem até ter uma identificação, uma assinatura, mas não têm autor, uma vez que não estão veiculados nas características de função-autor. Mas para Orlandi esta concepção é imprópria uma vez que para a $\mathrm{AD}$ o fato de um discurso apresentar unidade 
significa que ele tem autor. Os conceitos de unidade e textualidade são dependentes da autoria.

A discordância de Orlandi traz implicações para a apreensão do pensamento de Foucault, pois revela que a AD não apreende o ponto central das discussões e Foucault que diz respeito às conseqüências das relações (não está faltando algo aqui, está meio capenga) de poder na práxis humana. As considerações de Foucault mostram que se um discurso não se identifica pela autoria, significa que tal discurso ou nunca será legitimado ou que se trata de um discurso cuja ordem não precisa ser controlada pela função-autor. Os discursos que não necessitam de autoria na sua circulação são os que estão sob outros mecanismos de coerção tais como as coerções jurídicas, por exemplo. Desse modo, ao afirmar que um texto pode até não ter autor específico mas, pela função-autor, sempre se imputa uma autoria a ele,... Orlandi evidencia que desconsidera as características das relações de poderes que envolvem um texto/discurso legitimado pela função-autor. Ao imputar a função-autor a qualquer texto, a AD trata o conceito como sendo apenas mais um termo, um sinônimo de autor, que é utilizado apenas como uma identidade autoral alternativa, um outro tipo de assinatura, sem que seja relevante considerar as implicações histórico-políticas envolvidas em tal conceito.

Ainda que alguns termos utilizados por Foucault tais como sujeito, discurso, autor sejam os mesmos da $\mathrm{AD}$, o seu objetivo não é a análise sistemática de discurso. Ele faz análise do discurso, na qual o discurso sempre é visto como elemento que controla e é controlado pelo poder em domínios específicos. Suas discussões não buscam regularidades discursivas para a identificação do sujeito através de conceitos e teorias em análise de discurso. Foucault, na observação da atuação dos poderes, preocupa-se em enxergar as forças de controle do discurso onde elas menos se revelam, onde elas não se mostram em caráter regular e homogêneo. Para ele, o que interessa é observar as forças que conseguem destruir o discurso enquanto acontecimento. Ou seja, sua preocupação é observar como o poder controla o sujeito discursivo impondo limites ao discurso. Suas considerações percebem como este sujeito, que se vê obrigado a conviver na multiplicidade de discursos, é enredado nas malhas do poder e também como este sujeito promove resistências nos domínios locais de que faz parte. Ao observar as características da função-autor, Foucault consegue mostrar como o poder controla a literatura. Ele expõe o autor literário como apenas mais um indivíduo que atua em liberdade controlada, na forma em que os poderes determinam. Assim, para Foucault é mais produtivo, para a sobrevivência do sujeito nas redes do poder, o entendimento de como este sujeito se relaciona com o poder e não apenas como o poder o revela, o identifica. 
Desse modo, se o objetivo da AD é a identificação do autor pelas supostas ideologias que o controlam, para Foucault (2001-p.271) é mais produtivo localizar o espaço deixado vago pela “desaparição” do autor e entender como e porque ele é ocupado. Isto implica a razão de certos discursos serem legitimados pela função-autor. Para Foucault o que deve ser analisado são os locais preparados para os novos sujeitos. É necessário detectar o que ocorre quando o autor “desaparece”. Quando um espaço é deixado vago é preenchido, ocupado por outros; outros sujeitos se apropriam do discurso e tal desaparecimento e nova apropriação sempre envolvem o poder. Isto foi o que ocorreu caracterizando o surgimento da funçãoautor. Quando a morte do autor foi decretada pela crítica e pela filosofia foi preciso criar um substituto para legitimar o texto literário - surgiu então o complexo função-autor. Assim, a função-autor não é apenas um termo que pode ser aplicado a qualquer discurso/texto, pois a razão de sua existência está firmada em uma autorização que se diferencia de outros tipos de texto.

O conceito função-autor alerta que é preciso entender por que as forças de poder resolveram dizer que não interessa a vida de Proust, de Kafka; que suas identidades enquanto indivíduos deveriam desaparecer, que o que interessa são suas obras independentes - que o sujeito não é importante uma vez que a escrita e a noção de obra bastam para o que interessa da literatura. O raciocínio de Foucault aponta que tal concepção envolve o poder que controla o discurso através da legitimação do prestígio da escrita e da noção de obra. Assim, se dita que o valor de uma narrativa escrita é superior a uma narrativa perpetuada na oralidade, por exemplo. E também que um texto apenas tem valor literário se faz parte de um cânone de obra.

Ao identificar o conceito função-autor, Foucault mostra como o poder cria mecanismos para perpetuar o controle e/ou para intensificá-lo. Quando o poder determina que os sujeitos de certos discursos desapareçam em favor de uma compreensão mais "purificada” desses discursos, o objetivo é controlar o conhecimento reflexivo e crítico. Se realmente o autor tivesse saído de cena, como prega a crítica e a filosofia, qualquer um poderia se apropriar do discurso e isto colocaria em risco o poder. Assim, Foucault observa que a morte do autor é uma falácia, é uma jogada de regras ocultas, decretadas pelo poder que almeja controlar sem ser identificado. O autor está bem vivo (e bem controlado) através do mecanismo da função-autor, nos textos em que sua presença é necessária. 


\section{REFERÊNCIAS BIBLIOGRÁFICAS}

AUTHIER-REVUZ, J. Heterogeneidades enunciativas. Cadernos de Estudos Lingüísticos. Campinas, UNICAMP/IEL, n. 19, 1990.

BAKHTIN, Mikhail M. Problemas da poética de Dostoievski. Rio de Janeiro: Forense Universitária, 1981.

BAKHTIN-VOLOCHINOV. Marxismo e Filosofia da Linguagem. São Paulo: Editora Hucitec, 1997.

BECHEL, Maria C. B. A leitura compreensiva em espanhol língua estrangeira: como trabalhar? Que outros caminhos empregar? Curitiba, 2006. 108 f. Dissertação (Mestrado em Estudos Lingüísticos) - Setor de ciências Humanas Letras e Artes, Universidade Federal do Paraná.

BRANDÃO, H. N. Introdução à Análise do Discurso. 4. ed. Campinas, SP: Editora da UNICAMP, 1995.

CASTRO, Gilberto. Em busca de uma lingüística sociológica: contribuições para uma leitura de Bakhtin. Dissertação (Mestrado em Lingüística de Língua Portuguesa). Curitiba: UFPR,1993.

PÊCHEUX, Michel; DAVALLON, Jean; ACHARD, Pierre; DURRAND, Jacques; ORLANDI, Eni. Papel de memória. Tradução de José Horta Nunes. Campinas: Pontes, 1999.

DELONG, Silvia Regina. As noções de frames e esquemas no processo de leitura compreensiva em espanhol língua estrangeira. Curitiba, 2005. 151 f. Dissertação (Mestrado em Estudos Lingüísticos) - Setor de ciências Humanas Letras e Artes, Universidade Federal do Paraná.

DUCROT, Oswald. O dizer e o dito. São Paulo: Pontes, 1987.

DUNIN, Miriam P. M. F. Les Frustrés e a vanguarda parisiense dos anos 70: o modo de expressão de um sujeito em crise. Curitiba, 2005. 158 f. Dissertação (Mestrado em Estudos Lingüísticos) - Setor de ciências Humanas Letras e Artes, Universidade Federal do Paraná.

FREITAS, M. A. Educação e ensino de língua estrangeira hoje: implicações para a formação de seus respectivos profissionais e aprendizes. In: VIEIRA ABRAHÃO, M. H. (Org.) Prática de ensino de língua estrangeira: experiências e reflexões. Campinas: Pontes Editores, 2004. 
FOUCAULT, Michel. A ordem do discurso. Trad. de Laura F. A Sampaio. São Paulo: Ed. Loyola, 2004.

O que é um autor? In: Estética literatura e pintura, música e cinema. (De quem é o livro?) Trad. Inês AD. Barbosa. Rio de Janeiro: Forense Universitária, 2001.

Microfísica do poder. Rio de Janeiro: Ed. Paz e Terra, 2004.

HAROCHE, C. Fazer dizer, querer dizer. Tradução de Eni Orlandi. São Paulo: Editora Hucitec, 1992.

JORDÃO, C. M. O ensino de línguas estrangeiras: de código a discurso. Curitiba, 2006 (mimeo).

. O professor de língua estrangeira e o compromisso social. In: CRISTOVÃO, V.

et al (Orgs.) Construindo uma comunidade de formadores de professores de inglês. Londrina, 2005.

KRAMSCH, C. Social discursive constructions of self in L2 learning. In: LANTOLF. J. (Ed.), Sociocultural theory and second language learning. New York: Oxford, 2000, p. 133-153.

MUSSAliM, F. Análise do discurso. In: MUSSAliM, F.; BENTES, A. C. (Org.). Introdução à lingüística: domínios e fronteiras. 2. ed. São Paulo: Cortez, 2001. p. 101-142.

MUSSALIM. F.; BENTES, A C. Introdução à lingüística: domínios e fronteiras. São Paulo: Cortez, v. 2, 2003.

ORLANDI, Eni P. Análise de discurso: princípios e procedimentos. 5 ed. Campinas: Pontes, 2003.

POSSENTI, S. Teoria do discurso: um caso de múltiplas rupturas. In: MUSSALIM, F.; BENTES, A. C. (Org.). Introdução à lingüística: fundamentos epistemológicos. São Paulo: Cortez, 2004. p. 353-392.

SANTOS, Edleise M. O. Abordagem comunicativa intercultural (ACIN): uma proposta para ensinar e aprender língua no diálogo de culturas. Campinas, 2004. 440 f. Tese (Doutorado em Lingüística Aplicada) - Instituto de Estudos da Linguagem da Universidade Estadual de Campinas. 